\title{
Sistem Informasi Penjualan Berbasis Web Pada RM Sinar Minang
}

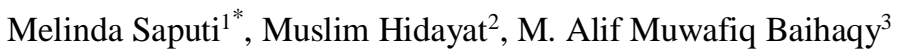 \\ 1,2,3 Manajemen Informatika, Fakultas Teknik dan Ilmu Komputer, Universitas Sains Al-Qur;an \\ Email: ${ }^{1}$ melindasaputri01@gmail.com, ${ }^{2}$ muslim_h@ unsiq.ac.id, ${ }^{3}$ aviq.baihaqy@ gmail.com
}

\begin{abstract}
Rumah Makan (RM) Padang is a restaurant business that sells or serves a variety of Minangkabau culinary or cuisine originating from West Sumatra. This restaurant is very famous in Indonesia and even the world. One of them is RM Padang Sinar Minang which is in Purbalingga, the restaurant provides a lot of food menus. Some of them are rendang, minced, gravel, snapper, tripe and iso. In monthly reporting activities, at RM Sinar Minang, the handwriting system is still being applied (manual). Admin difficulties in writing handwritten financial reports (manual) and in the payment system. whose sales records are still handwritten (manual), of course this kind of activity must be updated with the development of technology. The writing of financial statements that occurs is the amount of money that is at the cashier with the amount of money that is on the record of the food sold is not in sync / not the same. So it can be concluded that in writing the record of the food sold, there were problems such as forgetting to write the food that had been sold. Based on these things, the idea emerged to create a Web-Based Sales Information System at RM Sinar Minang. This system is expected to make it easier for admins/owners to collect data and can serve as a neat monthly report for agencies.
\end{abstract}

Keywords: Information system, RM Padang Sinar Minang, Website

\begin{abstract}
ABSTRAK
Rumah Makan (RM) Padang adalah suatu bisnis rumah makan yang menjual atau menghidangkan berbagai ragam kuliner atau masakan Minangkabau yang berasal dari Sumatra barat. Rumah makan ini amat terkenal di Indonesia bahkan dunia. Salah satu nya adalah RM Padang Sinar Minang yang berada di Purbalingga, dirumah makan tersebut menyediakan banyak sekali menu makanan. Beberapa di antaranya yaitu rendang, cincang, kikil, kakap, babat dan iso.Dalam kegiatan laporan bulanan, di RM Sinar Minang masih diterapkan system tulis tangan(manual).kesulitan admin dalam penulisan laporan keuangan yang ditulis tangan(manual) dan dalam system pembayaran yang catatan penjualannya juga masih ditulis tangan(manual), tentu kegiatan seperti ini harus diperbaharui dengan berkembangnya teknologi. Penulisan laporan keuangan yang terjadi adalah jumlah uang yang berada di kasir dengan jumlah uang yang berada pada catatan makanan yang terjual tidak singkron/tidak sama. Jadi bisa di simpulkan dalam penulisan catatan makanan yang terjual terjadi kendala seperti lupa menulis makanan yang sudah terjual.Berdasarkan hal-hal tersebut, muncullah gagasan untuk membuat Sistem Informasi Penjualan Berbasis Web pada RM Sinar Minang. Sistem ini diharapkan akan memberikan kemudahan bagi admin/pemilik dalam melakukan pendataan dan bisa sebagai laporan bulanan yang rapi untuk instansi.
\end{abstract}

Kata Kunci: Sistem informasi, RM Padang Sinar Minang,Website.

\section{Pendahuluan}

Dalam menghadapi perkembangan teknologi informasi yang semakin mendominasi segala bidang kehidupan, terutama dalam sektor usaha atau bisnis.Dalam lingkungan perusahaan, teknologi informasi sangat dibutuhkan[1]. Komputer merupakan salah satu alat bantu yang mutlak diperlukan sebagai produk teknologi informasi. Tidak dapat dipungkiri bahwa komputer memegang peran penting dalam kemajuan dan perkembangan perusahaan.Penerapan sistem infromasi menjadi kebutuhan yang mutlak dan dapat memberikan keunggulan kompetitif. Seiring dengan perkembangan teknologi informasi, telah banyak sistem penjualan yang mengalihkan sistem manual ke sistem komputerisasi [2]. Hal ini dilakukan guna meningkatkan dan mempercepat proses kerja 
pengolahan data. Untuk memulai suatu pengalihan sistem manual ke komputerisasi perlu dilakukan penelitian, studi kelayakan, sebelum bisa diterapkan pada pengolahan data yang bersangkutan [3].

Di RM Padang Sinar Minang saat ini belum menggunakan teknologi untuk sistem pembayaran dan membuat laporan keuangan. Karena secara manual untuk pencatatan laporan masih menggunakan penulisan tangan, maka diperlukan sistem baru untuk memasukan data yang meliputi menu, transaksi dan laporan penjualan. Berdasarkan hal-hal tersebut, muncullah gagasan untuk membuat Sistem Informasi Penjualan Berbasis Web pada RM Sinar Minang. Sistem ini diharapkan akan memberikan kemudahan bagi admin/pemilik dalam melakukan pendataan dan bisa sebagai laporan bulanan yang rapi untuk instansi.

\section{Metode Penelitian}

\subsection{Metode Pengumpulan data}

Metode pengumpulan data yang di gunakan penulis untuk memperoleh data yang dibutuhkan yaitu observasi dan literatur Observasi adalah Pengumpulan data dengan melakukan pengamatan langsung terhadap data yang diperlukan dalam penyusunan laporan dan pembuatan aplikasi, serta tampilan user interface [4].

Sedangkan literatur adalah Pengumpulan data dengan melakukan studi pustaka yang mencakup buku-buku, diktat, laporan, makalah, artikel pada media cetak maupun media elektronik seperti internet serta buku petunjuk teknis terpadu [5]. Dari data-data yang diperoleh penulis gunakan sebagai bahan acuan untuk menyusun laporan.

\subsection{Metode Pengembangan Sistem}

Metode pengembangan Sistem yang digunakan pada penelitian ini menggunakan metode waterfall [6].

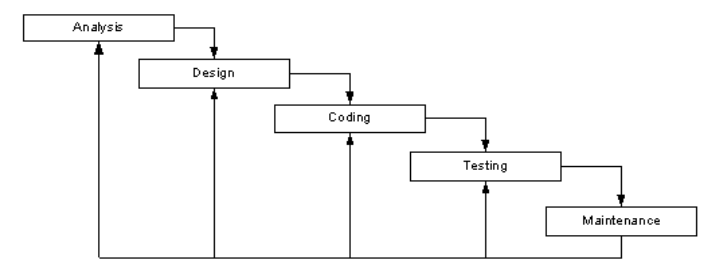

Gambar 1. Metode Waterfall

a. Tahap requirement atau spesifikasi kebutuhan sistem adalah analisa kebutuhan sistem yang dibuat yang dapat dimengerti oleh klien dan staf pengembang. Dalam tahap ini klien atau pengguna menjelaskan segala kendala dan tujuan serta mendefinisikan apa yang diinginkan dari sistem. Setelah dokumen spesifikasi disetujui maka dokumen tersebut akan menjadi kontrak kerja antara klien dan pihak pengembang.

b. Tahap selanjutnya adalah desain, dalam tahap ini pengembang akan menghasilkan sebuah arsitektur sistem secara keseluruhan. Dalam tahap ini menentukan alur perangkat lunak hingga pada tahap algoritma yang detail.

c. Selanjutnya tahap Coding, yaitu tahapan dimana keseluruhan desain diubah menjadi kode-kode program. kode program yang dihasilkan masih berupa modul-modul yang selanjutnya akan di integrasikan menjadi sistem yang lengkap untuk meyakinkan bahwa persyaratan perangkat lunak telah dipenuhi.

d. Tahap selanjutnya adalah Testing oleh klien, klien menguji apakah sistem tersebut telah sesuai dengan kontrak yang telah disetujui sebelumnya.

e. Tahap akhir adalah pemeliharaan (maintenance) yang termasuk diantaranya instalasi dan proses perbaikan sistem sesuai kontrak.

\section{Hasil dan Pembahasan}

3.1. Perancangan Sistem

a. Use Case Diagram

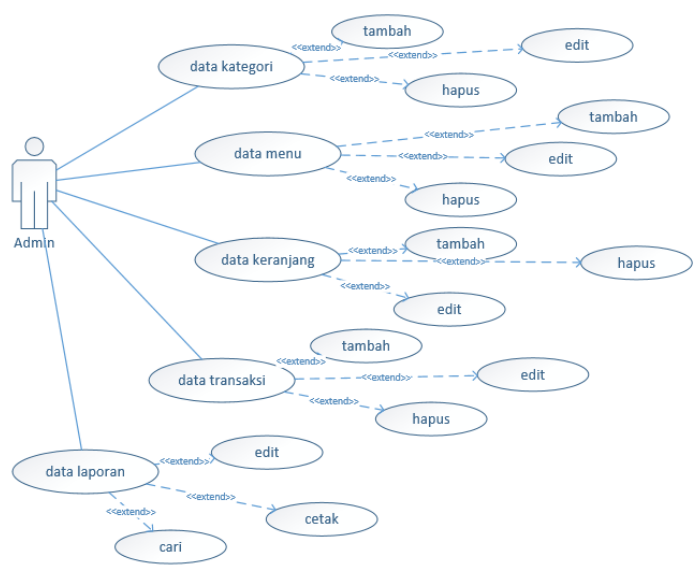

Gambar 2. Use Case Diagram

b. Class Diagram

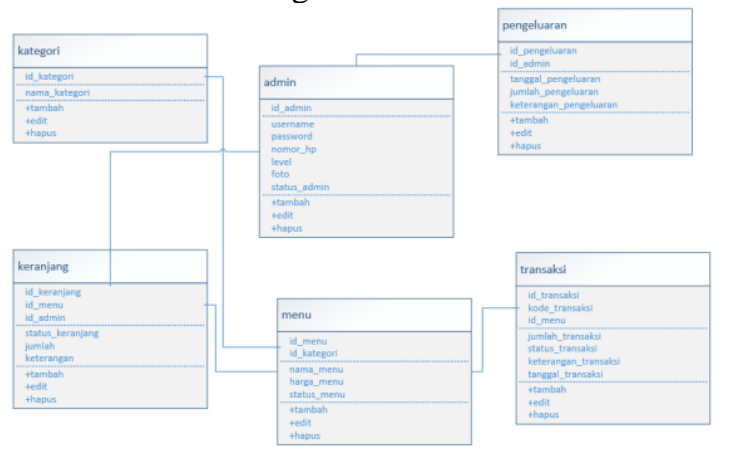

Gambar 3. Class Diagram

DOI: $\mathrm{xxxx}$

Lisensi: Creative Commons Attribution 4.0 International (CC BY 4.0) 
c. Entity Relationship Diagram (ERD)

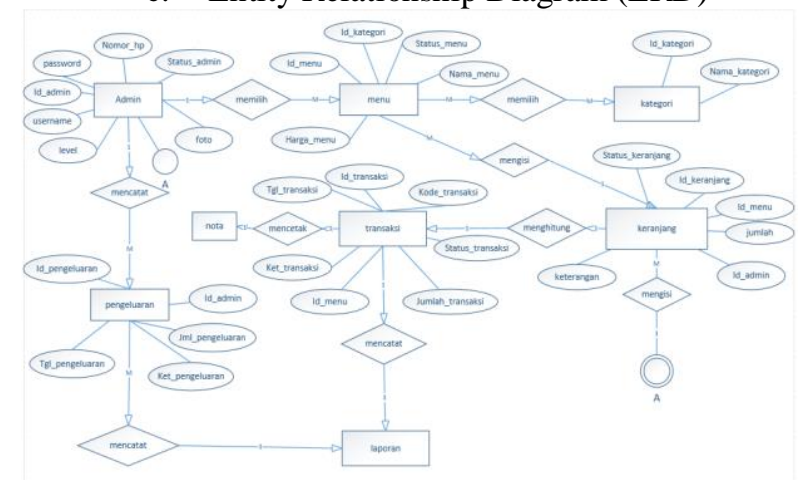

Gambar 4. Entity Relationship Diagram

3.2. Implementasi Sistem Informasi

a. Tampilan Halaman Login

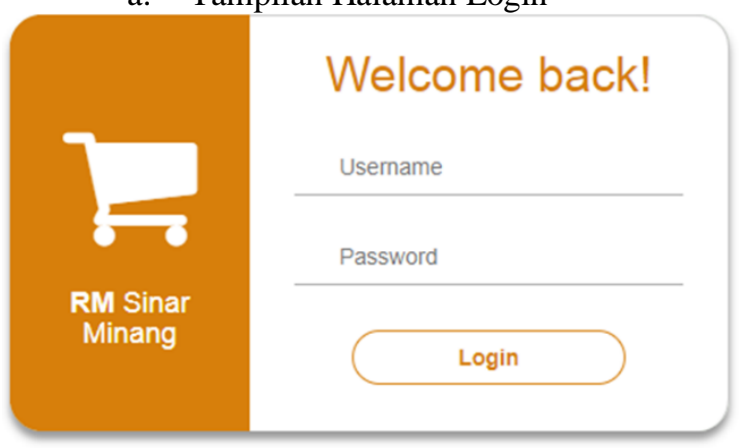

Coded with $\vee$ by Cimel.

Gambar 5. Tampilan Halaman Login

Pada saat pertama kali program dijalankan akan muncul Halaman Login dimana setiap user harus memasukkan username dan password, agar bisa masuk ke halaman yang telah disediakan
b. Tampilan Halaman Dashboard Admin

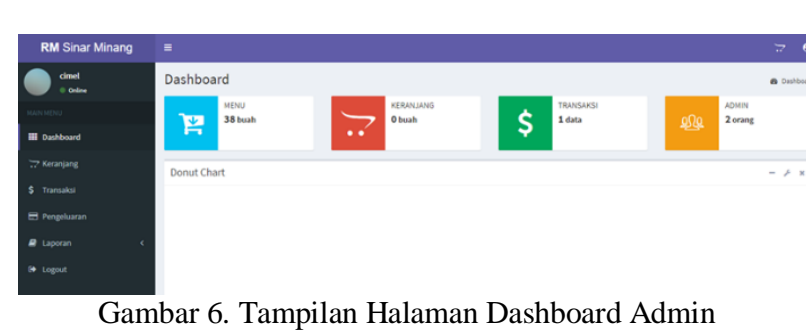

Merupakan tampilan setelah pengguna melakukan login. c. Tampilan Halaman Admin

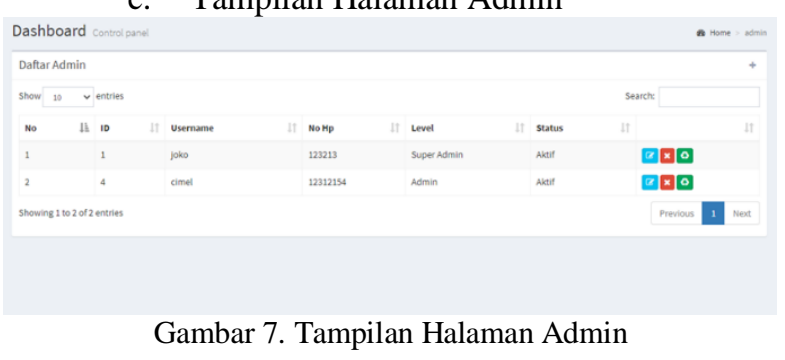

Tampilan halaman admin merupakan halaman untuk mengakses data admin.

\section{d. Tampilan Halaman Tambah Admin}

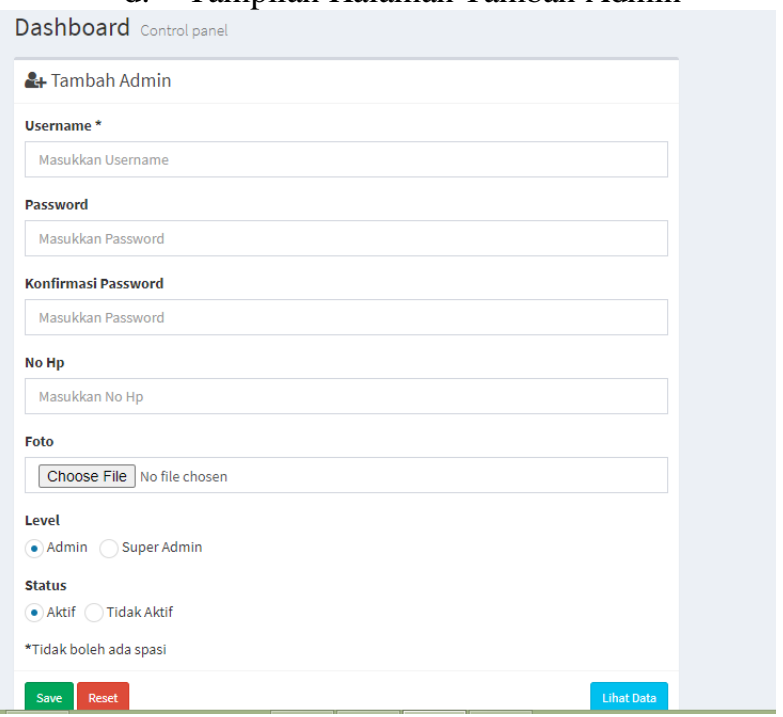

Gambar 8. Tampilan Halaman Tambah Admin

Tampilan halaman tambah admin merupakan halaman untuk menambahkan data admin.

\section{e. Tampilan Halaman Kategori}
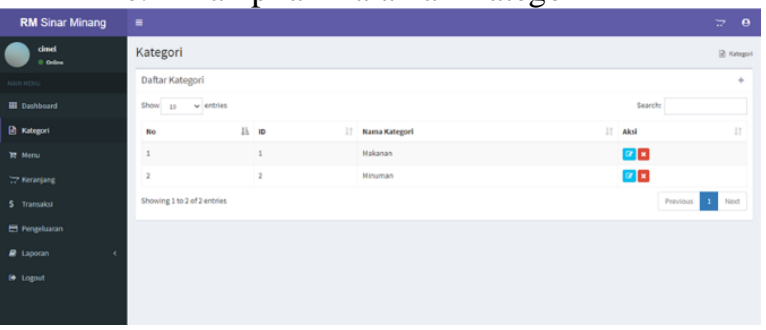

Gambar 9. Tampilan Halaman Kategori

Tampilan halaman kategori merupakan halaman untuk melihat halaman daftar kategori 


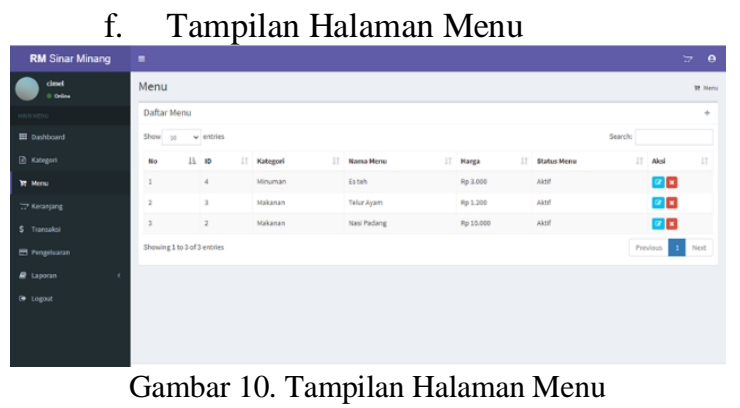

Tampilan halaman menu merupakan halaman untuk melihat daftar menu.

\section{g. Tampilan Halaman Keranjang}

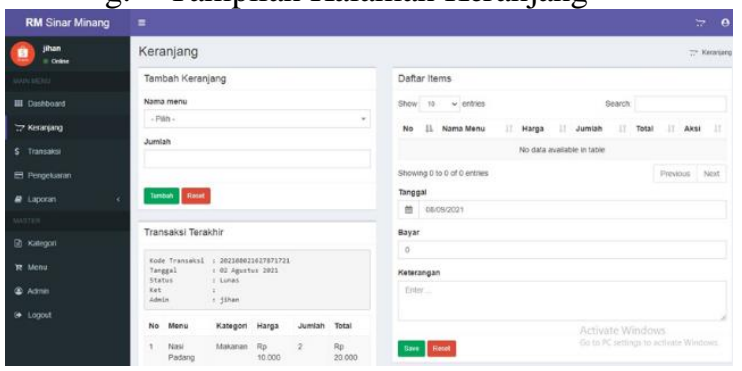

Gambar 11. Tampilan Halaman Keranjang

Tampilan halaman keranjang merupakan halaman untuk melihat data keranjang.

\section{h. Tampilan Halaman Transaksi}

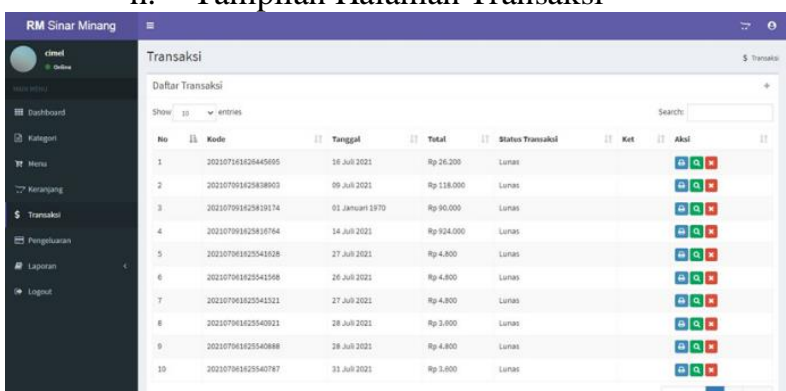

Gambar 12. Tampilan Halaman Transaksi

Tampilan halaman transaksi merupakan halaman untuk transaksi.

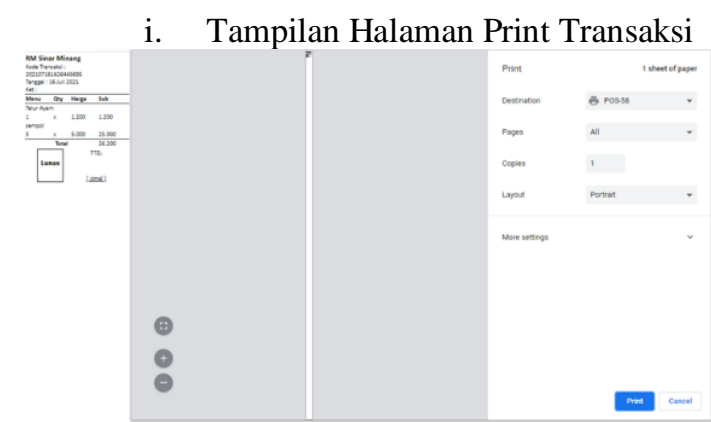

Gambar 13. Tampilan Halaman Print Transaksi
Tampilan halaman print transaksi merupakan halaman untuk melihat faktur pembayaran dan melakukan print transaksi.

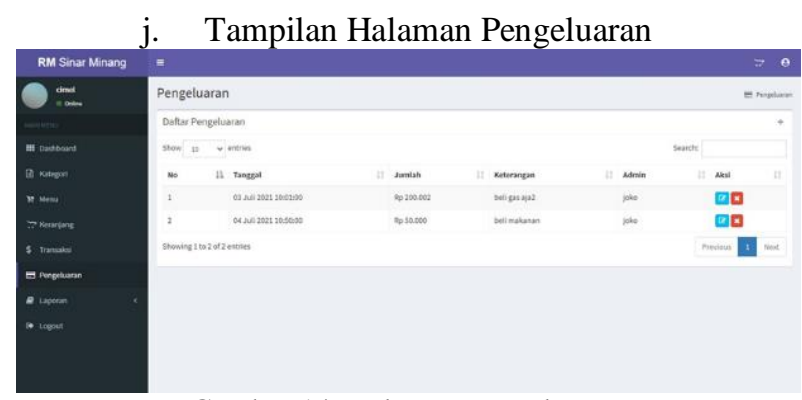

Gambar 14. Halaman Pengeluaran

Tampilan halaman pengeluaran merupakan halaman untuk melihat daftar Pengeluaran.

\section{k. Tampilan Halaman Laporan Pengeluaran}

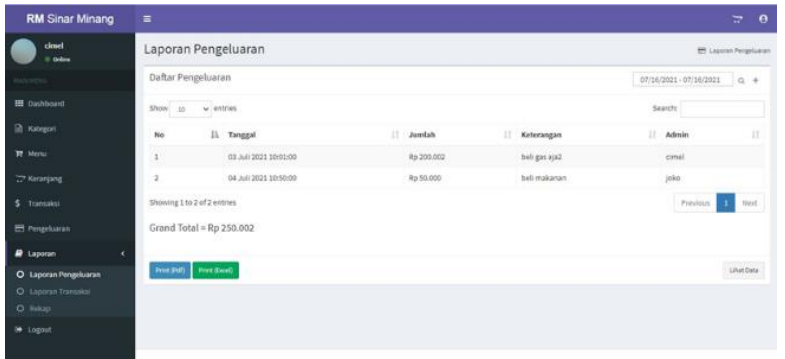

Gambar 15. Tampilan Halaman Laporan Pengeluaran

Tampilan halaman laporan pengeluaran merupakan halaman untuk melihat laporan pengeluaran.

\section{Tampilan Halaman Laporan Transaksi}

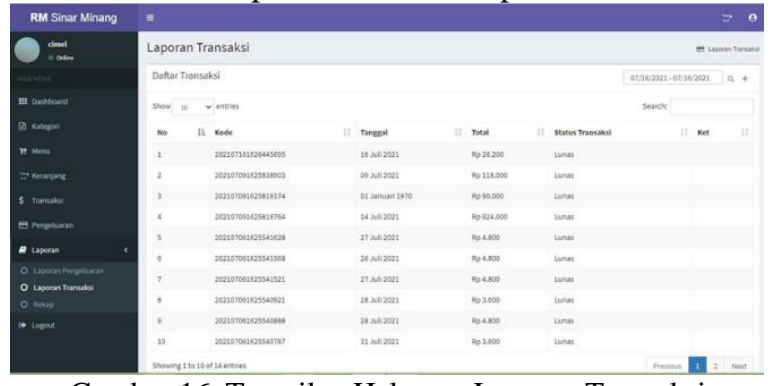

Gambar 16. Tampilan Halaman Laporan Transaksi

Tampilan halaman laporan transaksi merupakan halaman untuk menghapus data tempat.melihat laporan transaksi

\subsection{Pengujian}

Pengujian pada sistem yang dibangun dilakukan dengan pengujian Black-box. Terdapat 25 Scenario pengujian. Hasil dari 25 Scenario tersebut 24 Scenario berhasil di uji. Sehingga Berdasarkan hasil pengujian yang telah dilakukan, dapat diambil kesimpulan bahwa

DOI: $\operatorname{xxxx}$

Lisensi: Creative Commons Attribution 4.0 International (CC BY 4.0) 
pada beberapa proses yang ada dalam sistem mungkin Referensi

saja masih memiliki kesalahan kecil. Karena pada pengujian black-box memang tidak menampilkan pengujian sistem secara lebih detail. Namun apabila dilihat secara fungsinya Sistem Informasi Penjualan Berbasis Web Pada RM Sinar Minang ini sudah dapat melakukan fungsinya sesuai dengan yang diharapkan oleh pihak pengguna.

\section{Kesimpulan}

Dengan adanya sistem informasi penjualan, maka saat ini sistem pembayaran dan laporan penjualan menjadi lebih efisien, sehingga dapat melakukan pembayaran dengan menggunakan web yang sudah dibuat dan data otomatis langsung masuk ke dalam laporan. Digunakannya sistem informasi penjualan, maka pegawai ataupun admin bisa memantau makanan atau minuman yang sudah terjual sama atau tidak dengan penghasilan yang di dapat.

11] Pangaribuan, Gref Venty Yuniar. "Analisis Perencanaan Strategis SI/TI Pada PT. Tao Berlian Jaya Dengan Menggunakan Metode Ward Peppard". Diss. Universitas Atma Jaya Yogyakarta, 2021.

[2] ISTIQOMAH, NUR AIDAH. "SISTEM INFORMASI AKUNTANSI PENJUALAN TUNAI PADA PT GRAHA OBOR WIJAYA CABANG SURABAYA". Diss. STIESIA SURABAYA, 2019.

[3] Apriliane, Evita. "TINJAUAN SISTEM INFORMASI AKUNTANSI PENJUALAN TENAGA LISTRIK PADA PT. PLN (PERSERO) UPJ BANDUNG TIMUR". Diss. Universitas Widyatama, 2009.

[4] Larasati, Hilari, and Siti Masripah. "Analisa dan perancangan sistem informasi pembelian grc dengan metode waterfall." Jurnal Pilar Nusa Mandiri 13.2 (2017): 193-198.

[5] Warsihna, Jaka, and J. Warsihna. "Meningkatkan literasi membaca dan menulis dengan teknologi informasi dan komunikasi (TIK)." Jurnal Kwangsan 4.2 (2016): 67-80.

[6] Asnawi, Muhamad Fuat, et al. "SISTEM INFORMASI MIGRASI SATELLITE BRISAT BERBASIS WEBSITE PADA PT. SELINDO ALPHA." IKRA-ITH INFORMATIKA: Jurnal Komputer dan Informatika 2.3 (2018): 71-79.

DOI: $\operatorname{xxxx}$

Lisensi: Creative Commons Attribution 4.0 International (CC BY 4.0) 